\title{
Agricultural Defense of São Paulo: twelve years of soil preservation and rehabilitation at Rio do Peixe watershed, promoting conservation agriculture
}

\author{
Oswaldo Vischi Filho' ${ }^{1}$, Oscar Kanno², Roberto Arabori², João Flávio Caldas², Raul \\ Penteado $^{2}$, Edna Aparecida Scachetti², Jorge Quiessi², and Marcelo Camargo ${ }^{2}$ \\ ${ }^{1}$ Secretaria de Agricultura e Abastecimento do Estado de São Paulo \\ ${ }^{2}$ Secretariat of Agriculture of the State of São Paulo
}

May 5, 2020

\begin{abstract}
The objectives of this study are to test innovations for the farms diagnosis, to locate erosion and to correct them with changes in the way of soil management, to aiming transforming Rio do Peixe Watershed properties that were degraded, rehabilitating them, promoting conservationist agriculture whit evaluating the results through remote sensing and water quality indicators. Secretariat of Agriculture of São Paulo State (SA), responsible for applying the Soil Conservation Law, has been carrying out this study for 20 years, working up 772,000 ha, with 19,846 agricultural properties. In 2019, it turned twelve years of inspection/monitoring at the Rio do Peixe Watershed. From 2007 to 2017 14,076 ha were inspected in Vera Cruz, with notification of 94 properties that went from degraded into agricultural companies. In Ocauçu, 82 properties were notified, on 8,125 ha. Besides other tested methodologies, model airplanes and helicopters, in Marília the Innovative CAD Methodology was used, which allowed 52 properties to be inspected on 27,000 ha from 2017 to 2019 . There were transformations of degrading agriculture into conservation agriculture on the study carried out at Rio do Peixe Watershed. Property with degraded pasture turned into an agricultural area, with the no-tillage system. Pastures were recovered with the Integrated Crop-Livestock Systems, where the occupancy rate was increased by $31 \%$ comparing to the original situation. It is a great work that benefits the Watershed farmers and the population in the region, including improving the water quality that supplies Marília. It is the SA "Caring for the Well-Being of Society".
\end{abstract}

\section{INTRODUCTION}

São Paulo State Secretariat for Agriculture and Supply, through the Coordination of Agricultural Defense (CDA), is responsible for applying the Law on Use, Conservation and Preservation of Agricultural Soil - State Law $n^{\circ}$. 6.171 / 88 - (São Paulo, State, 1988) to monitor and discipline the soil use and conservation to fight soil erosion. This work has been carrying out for 20 years with very positive results, mainly in inspections carried out at Watersheds. The area of the state occupied by agriculture, which is called the agricultural area of the state of São Paulo, is approximately 18 million hectares, with 330 thousand agricultural properties. During that period, 772,000 hectares were already worked on 19,846 agricultural properties that were notified and rehabilitated agroecologically. Using conservation legislation as a tool, the ideal work unit for carrying out soil conservation study is the watershed. The watersheds have the important function of regulating the water balance, in addition to housing agricultural production and promoting the storage of rainwater, which seeps into the soil and is made available to rivers throughout the year. The degradation of the watershed is related to the lack or deficiency of vegetal cover from cultures that occupy the soil and has as a consequence the erosive processes that cause the silting of the watershed water network, interfering in the quantity and quality of the water (Rodrigues et al., 2015). The first principle of soil conservation is soil cover, whether 
vegetable or mulch. The use of conservationist practices, such as the use of varieties that provide greater vegetal coverage of the soil, reducing the direct impact of raindrops on the soil surface, reduces the soil losses, water, organic matter, and nutrients because of water erosion (Silva et al., 2005; Rodrigues et al., 2015). The inappropriate use of agricultural soils causes the gradual loss of its productive capacity and the contamination of water resources by sediments, resulting from the erosion process (Lelis \& Calijuri, 2010). This occurs as a result of the inexistence, or because of the erroneous adoption of conservationist practices in the cultivation areas of agricultural properties, which can transform a large river into a sprawling stream, a fact commonly verified in Brazil, mainly in pasture areas (Menezes et al., 2009). Irrational soil management makes production unfeasible and compromises the balance of ecosystems (Santos et al., 2007) and soil cover, which is a form of management for a specific crop, in a management system and specific locations, represent a joint effect in reducing water erosion (Silva et al., 2009). The second principle of soil conservation is to prevent the surface run-off regime from changing from laminar to turbulent and, for that, the construction of an agricultural terracing system is carried out, which has the function of sectioning the length of the ramp and promoting the infiltration of soil water. According to Pruski (2006), the more the soil surface is protected by vegetation cover, against the rain action, lower the propensity for erosion to occur. Studies by Minella et al. (2007) to identify the origin of sediments at watersheds, concluded that the areas of crops are the main sources of sediments and suggested that programs for the implementation of conservationist soil management practices are essential. By adopting proper management and mitigating actions to recover the impacted areas, there will be an improvement in water quality at the watersheds (Araújo et al., 2009). As a final product of soil conservation, its contribution to minimizing floods during periods of heavy rainfall and increased availability of water in the dry period of the year is considered.

At the Rio do Peixe watershed, in June 2007 the inspection activities began, which consists of the preliminary survey (PS) stages, the visit to the properties (inspection), the presentation of technical conservation projects for each property and ends with the rehabilitation of all visited and notified properties. To carry out the work, at the Vera Cruz section of the watershed, the conventional methodology was used in 2007, accomplishing this stage in December 2011, where 14076 ha were evaluated; in the Ocauçu stretch (from 2011 to 2015), 8,175 ha were evaluated, making a total of 22,251 ha, that is, 216 ha per month, as the study was carried out by a team of four Agronomists who worked one week per month, for 103 months. The CDA inspection/diagnosis methodology (conventional) was developed as from 1999, by a technical group of Agricultural Engineers, published in 2003 and that was improved in 2017, receiving the name of Innovative CDA Diagnostic Methodology (Vischi Filho et al., 2017). This came out because action strategies needed to be created to streamline all of this demand. Several options for technological innovations were tested, including the use of model aircraft, helicopter and drone, however, the results were only favorable when a new method of work was developed. The pilot project of the CDA Innovated methodology was carried out at the Rio do Peixe Watershed, in a 53 thousand hectares stretch, located in Vera Cruz, Ocauçu and Marília (Vischi Filho et al., 2018). In this study, with an emphasis on the inspection of Rio do Peixe watershed, the type of intervention aimed at transforming conventional and soil-degrading agriculture into conservationist agriculture, implementation conservationist technical projects that contemplated this novelty. Conservation Agriculture is an agricultural system that promotes the maintenance of permanent soil cover, minimal soil disturbance or no-tillage and the diversification of plant species. It increases biodiversity and natural biological processes above and below the soil surface, which contributes to increasing the efficiency of water and nutrients use and to improve and sustain agricultural production (FAO, 2019). On June 15, 2019, it turned twelve years of activities to inspect the use and conservation of the soil at Rio do Peixe watershed, in the stretches located in Vera Cruz, Ocauçu and Marília. The objectives of this study were to test innovations for diagnosis of agricultural properties, to locate erosions and to correct them with changes in the ways of soil management, aiming at transforming the degraded agricultural properties at Rio do Peixe watershed into rehabilitated properties, promoting conservationist agriculture and evaluating the results through remote sensing and water quality indicators. This is a great study by the São Paulo State Secretariat of Agriculture and Supply, which brings benefits to farmers whose properties make up Rio do Peixe watershed and especially to the entire population of this region that has benefited from the development of this study, including in improvement of the water quality that supplies the cities, mainly Marília (216,684 inhabitants) 
and Presidente Prudente (227,072 inhabitants) that capture waters from Rio do Peixe for public supply. It is the Secretariat of Agriculture "Caring for the Well-Being of Society".

\section{MATERIALS AND METHODS}

This work was carried out in the stretch of the Rio do Peixe watershed (Rio do Peixe watershed), located in Vera Cruz, Ocauçu and Marília, SP, Brazil, under coordinates S22 ${ }^{\circ} 14^{\prime} 52.68^{\prime \prime}$, W49 $44^{\prime} 59.97^{\prime \prime}$, start and end under coordinates S22 $2^{\circ} 8^{\prime} 13.28^{\prime \prime}$, W50 $2^{\prime} 54.22^{\prime \prime}$, Datum WGS 84 (Figure 1). The climate of the region is the humid subtropical of the Cwa type, according to the Köppen classification, with temperatures in the warmest month above $29.7^{\circ} \mathrm{C}$ and in the coldest month, below $10.6^{\circ} \mathrm{C}$, with rainfall annual average of $1,193 \mathrm{~mm}$. The predominant soils are Red-Yellow Ultisol, Abrupt, moderate horizon A, sandy/medium texture and Litolic Entisol, eutrophic (Santos et al., 2018). The geological formation consists of rocks from the Bauru Group, covered by neocenozoic sediments (Bezerra et al., 2009). The predominant relief is smooth-undulating, in the western plateau of São Paulo and, in the region of the depression, it is strongly undulating in the escarpments (Itambé) that separate the plateau from the depression.

Inspection and agro-environmental rehabilitation work at Rio do Peixe watershed started on June 15, 2007, and is ongoing until today, in 2020, with inspections carried out on all properties that are part of these stretches of the watershed, where properties whit erosion were observed and also soil degrading processes, seen during diagnosis, which were classified according to the legislation in force in the State of São Paulo (São Paulo, State, 1988). After the detection of erosions, from the report generated during the visits, the owners of the farms were notified to readjust the properties based on technical conservation projects, specific to each one of them. The CDA Staff, composed of four Agricultural Engineers, during a week, monthly, visited each property two to five times during the implementation of the project, the first time during the diagnosis, in monitoring the execution of the technical project and in releasing the property after the implementation of conservationist practices. The other remaining properties that complied with the land use and conservation legislation, received a document informing them of this compliance. The data collected during the diagnosis were inserted into a specific database and worked according to the methodology described by Vischi Filho et al. (2016). The evaluation of the results obtained with soil conservation, through the improvement of vegetation cover and resulting from changes in soil and water management practices were proven by comparing the state of the art (before assessment/study - T1) to the results obtained (after the implementation of technical projects - T2), using Google Earthß Pro images, using the historical images tool (years: 2002, 2006, 2012, 2013, 2017 and 2018) to evaluate the post-agro-environmental rehabilitation of properties (Figure 2). The measurement of soil losses and sediment input to the river were evaluated by water quality indicators evaluated by Turbidity, Suspended Solids, Phosphorus and Organic Carbon, which were measured through periodic water analysis of Rio do Peixe. As for the water quality indicators, the data collected was separated into two periods, considered as treatments, being: T1 - data referring to the period called BEFORE the study was carried out, considering the information from the years 2000 to 2007 and T2 - data referring to the period termed AFTER the study was carried out, considering the information from 2008 to 2018. The improvement in water quality was assessed by determining the indicators that were tabulated and compared using graphics prepared for each indicator for treatments T1 and T2 (Figure 3). These indicators were chosen because turbidity shows the sediment input in the waterbody as a result of erosion and the transport of these particles to the watercourse. The months were chosen as they have a higher probability of erosion, according to rainfall data, considering as the highest rainfall averages, the months of February, October and December, which were the months that sampled and analysed the water. To subsidize the turbidity and suspended solids assessments in water, the information of Setzer (1985) was used as a comparison. The samples to evaluate these measures are obtained in the watercourse, in the posts located downstream from the places where the watershed has the largest cultivated areas, which are located upstream. To apply the law for the use and conservation of agricultural soil, a diagnosis is made that consists of delimiting the watershed and visiting all the component properties of that watershed. This procedure is called a preliminary survey (PS) and has a high cost to be performed, in addition to being very time-consuming. The diagnosis is carried out with the aid of aerial images from Google Earth@ Pro, 
planialtimetric charts of scale 1: 50.000 and surveys "in loco" by Staff of Agronomic Engineers from CDA. After the inspections, the owner who is not complying with the legislation (São Paulo, State, 1988), is notified and presents a conservation project to recover that degraded area, respecting the class of land use capacity (Lepsch et al., 2015). After the project was implemented, with the area recovered and erosions controlled, it started to adopt conservationist practices that transform soil management into a conservationist. The present study deals with the inspection at a watershed, specifically Rio do Peixe watershed, stretches of Vera Cruz, Ocauçu and Marília, which correspond to 53 thousand hectares. Having the difficulty of traversing the 330,000 agricultural properties in the state of São Paulo, a new methodology for inspection was adopted, which was the Innovated CDA Methodology (Vischi Filho et al., 2017). The methodology consists in the use of the databases of the Rural Environmental Registry (CAR), the Animal and Vegetable Defense Management System (GEDAVE) and Aerial Images of Google Earthß) Pro, current, promoting an interface of this information with databases, performing diagnosis and inspection by remote sensing. After this step, the data obtained with the study carried out on Google Earth $\AA$ Pro and Excel $囚$, are checked in the field "in loco" and the inspection and consequent agri-environmental rehabilitation are finalized (Vischi Filho et al., 2018).

\section{RESULTS}

From 2007 to 2018, 14,076 ha were diagnosed in Vera Cruz, 9,027 ha in Ocauçu and 27,775 ha in Marília, out of a total of 53 thousand hectares, corresponding to the Rio do Peixe watershed stretch. In Vera Cruz, 94 agricultural properties were notified, out of a total of 176 properties. In Ocauçu, 82 agricultural properties were notified and in Marília, using the Innovative CDA Methodology (Vischi Filho et al. 2017 and 2018), in just nine months, 20 large agricultural properties and 32 small properties were inspected, with a total area approximately 27.7 thousand hectares. It was diagnosed and evaluated from January to November 2017, in just 9 months of work, 27,775 ha or 3086 ha per month. This methodology allows the strategy of evaluating, in detail, an area, which, according to the old methodology, would take 103 months to be carried out (8 years and 7 months) and in just nine months the work was accomplished generating time and cost savings, with income of $1377 \%$ favorable to the Innovated CDA Methodology. Erosions and other soil degradation processes are reported in Table 1. These inspections already carried out received the conservation technical projects for the areas and were implemented.

The results obtained with the changes in soil and water conservation management practices regarding the improvement of vegetation cover were confirmed by the evaluation of aerial images before the study was carried out - 2002 - and after the study was carried out - 2013 - (Figure 2). The results of the "in loco" survey for land use and occupation (Table 2) show that the following crops predominate at the Watershed: pastures with 30,472 ha, coffee with an area of 2,798 ha, fruit (mango, coconut, and citrus) with 136 ha, eucalyptus with 95 ha, vegetables with 60 ha, passion fruit with 15 ha, crops of annual cycle (corn and beans) with 181 ha, sugar cane with 37 ha and in the environmental condition, natural forest, with 10,606 ha that cover the slopes of the formation known as "Itambe".

The improvement in water quality caused by the control/minimization of erosive processes and sediments carried to the watercourse were confirmed by the water quality indicators: Turbidity, Suspended Solids, Phosphorus and Organic Carbon, analysing the representative graphics the results of these analyses (Figure 3 ). The Turbidity of the water evaluated from 2000 to 2007, considered as before the work was carried out (BEFORE - T1), presented average values of 192 NUT (Nephelometric Units of Turbidity), against the average values of 102 NUT, evaluated from 2008 to 2018, considered as after the completion of the study (AFTER - T2), a decrease of $53 \%$ in the average values. The suspended solids evaluated from 2000 to 2007 (T1), presented average values of $297 \mathrm{mg} \mathrm{l-1}$ (milligrams per litre), against the average values of $132 \mathrm{mg} \mathrm{l-1,}$ evaluated from 2008 to 2018 (T2), a 44\% drop in average values. The phosphorus evaluated from 2000 to 2007 (T1), presented average values of $0.18 \mathrm{mg} \mathrm{l-1}$ (milligrams per litre), against the average values of 0.14 mg l-1, evaluated from 2008 to 2018 (T2), a $78 \%$ drop in average values. The Organic Carbon evaluated from 2000 to 2007 (T1), presented average values of $9.60 \mathrm{mg} \mathrm{l-1}$ (milligrams per litre), against the average

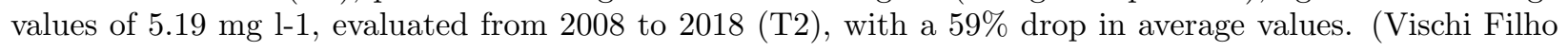


et al., 2019).

\section{DISCUSSION}

\subsection{Land Use and Occupation}

The following crops predominate in this stretch of Watershed: Pasture, Natural Forest and Coffee. The natural forest, considered the best vegetation cover, is present in an area corresponding to $21.16 \%$ of the area of this stretch of Rio do Peixe Watershed. Santos et al. (2014) evaluating a watershed with 11 thousand ha, located in Botucatu, SP, in relief conditions similar to Rio do Peixe watershed, in terms of land use and occupation found 1,109 ha of natural forest, corresponding to $9.95 \%$ of the watershed area, a situation that corresponds to less than half of the result found in the present study, showing that in this stretch of Rio do Peixe Watershed, the forest is more preserved. The last decades have been characterized by drastic changes in land use and occupation in the region, which for Zalidis et al. (2002) represented one of the main driving forces for environmental degradation, especially on soil and water.

As for the pasture area, there is an occupation in the studied section of 30,472 ha, representing $60.81 \%$ of the total area of the Watershed (Table 2). The results found are similar to those of Lima et al. (2004) who evaluated 43,228 ha of pasture area in a watershed in Ilha Solteira, which represents $66.79 \%$ of the total area. In the present study, one of the positive examples was the transformation of a property, which used to operate livestock, located in Ocaucu, SP, with a degraded pasture area of 500 ha. After carrying out the present study, these 500 ha were transformed into an agricultural area with the no-tillage system, intended for annual cycle crops, with rotation: brachiaria straw, soybeans, corn and wheat in winter (crop change and soil management). A new conservationist technology that was implemented in the region.

Using the images from the Google Earth(r) Pro to verify the effectiveness of the works implanted in the area occupied with pasture with the presence of erosive processes (Figure 2A and 2B), the action of agrienvironmental adequacy to contain the erosive processes was implemented and the control of the erosion in the area was accomplished with the construction of containment boxes on areas with pastures. There was an improvement in the visual aspect of the area comparing to soil conservation, in which case it was proven that pasture management with the use of hydraulic structures (containment boxes) favored the restoration of the area and the return of potential soil productivity.

Analysing Figures 2C, 2D, 2L and 2M, it can be seen that the change in management in coffee culture provided a positive change in the landscape, inferring that in addition to improving the landscape with more intense vegetation cover (Figures $2 \mathrm{D}$ and $2 \mathrm{M}$ ), there was an improvement in potential crop productivity. In the coffee culture, what contributed to the improvement of the soil conditions was the adequacy of the crop following the level of the ground and recovery of soil fertility. The soil conservation techniques applied in this case were sufficient to control erosive processes. In Figures $2 \mathrm{E}$ and $2 \mathrm{G}$, using the image comparison method, it can be seen that the agricultural terracing built in the area in question was efficient in controlling erosion processes at the property. According to Araujo et al. (2009) the use of appropriate management measures and erosion mitigating actions, with the recovery of the impacted areas, there will be an improvement in water quality and control of sediment production, minimizing silting and consequently, there will be an almost complete environmental rehabilitation. The comparison between aerial images from before (T1) and after (T2) was used to assess the efficiency of the results obtained, a method that was also used by Bezerra et al. (2012) who evaluated by photocomparation the vegetation cover and the potential of water in the soil aiming at the monitoring and recovery of degraded areas in Uberlandia, MG, and considered that the photocomparation with the supervised classification allowed to follow the development of the vegetation cover with grasses, as well as their relation to soil water potential. According to Menezes et al. (2009) with remote sensing, it was possible to verify the presence of areas already affected by inadequate management on areas with degraded pastures. These authors also highlighted the fact that native vegetation has been largely converted into pasture. Figures $2 \mathrm{~K}$ and $2 \mathrm{O}$, conversely, show the mechanical control of erosions with the construction of dams and terraces that altered the landscape of the place, previously degraded, into a pasture with productive capacity (Figures 2J and 2N). Figure 2J shows an old and eroded road that 
carried sediments to the bed of Rio do Peixe and which was corrected by building terraces (Figure $2 \mathrm{~K}$ ). It is important to observe the fact that there are practices focused on the conservation, which represents a large part of the Rio do Peixe Watershed section, besides promoting important benefits for soil conservation, it can be another factor that stimulates the increase in income for producers, once, with conserved pasture, there is a higher volume of biomass and, consequently, the possibility of higher animal density. An example of this statement is the pasture areas recovered with the adoption of the Integrated Crop-Livestock Systems (LIS), where the management of these pastures has changed, replacing the grass variety and providing pasture with good vegetal mass during the dry periods. This resulted in an occupancy rate of five Animal Units (AUs) per ha, as evidenced by the evaluation of 14 properties, wherein 10 of them, there was an average growth of $31 \%$ in the occupancy rate, compared to the original situation found before carrying out the inspection work. It corroborates with this information the study of Albernaz \& Lima (2007) who evaluated two subwatersheds, in Lavras, MG, occupied by pastures, according to conservationist practices: level planting, terracing, catchment basins, liming maintenance and inferred that at Ribeirao Santa Cruz sub-watershed (SW) more conservation practices are adopted than at SW Agua Limpa and the exposure of the soil to degradation was bigger at SW Agua Limpa. A similar result was observed by Zolin et al. (2011) stating that the biggest relative reductions in soil loss occurred on scenarios with conserved pasture, indicating that the optimization of soil conservation can be accomplished by adopting conservationist management practices for pasture recovery. According to Rodrigues et al. (2015) who analysed the role of vegetation in water interception and erosion control, at Rio Paraiso Watershed, in Sao Manuel, SP, the uncovered soil showed a 98.09\% increase in sediment production, when compared to soils with vegetation cover.

This study to inspect the use and conservation of the soil is important not only for the soil and water preservation, however, also for the rural producer to earn more money with his activity, a fact that can be proven by analysing Table 3, wherein most of the agricultural properties worked with the recovery of pastures, farmers had an increase of $31 \%$ in the occupation rates of these areas and with this, they will have a higher income and a greater profit in their activity.

\subsection{Water Quality Indicators (WQI)}

\subsubsection{Turbidity}

Analysing the turbidity data, suspended solids, phosphorus and dissolved organic carbon (Figures: 3 $\mathrm{A}, \mathrm{B}, \mathrm{C}$, and D), it ensures that the data from treatment T2 are more uniform or stable than in T1 for these indicators. When analysing Figures $3 \mathrm{~A}$ and $3 \mathrm{~B}$, related to water turbidity, in previous years the implementation of the study (T1) and after the implementation of the study (T2), it observes that, on average, water turbidity was lower in the months of February and December when we compare (T2) with the situation before the implementation of the study (T1). For the T1 treatment, the values were higher than the CONAMA standard (Conama, 1986), which is 100 NUT (Figure 3A), in the average of February and December. In T2 treatment, the average values were 102 NUT, except for February 2009, 2014, 2017 and 2018; October 2009, 2012 and 2018; December 2009 and 2015 (Figure 3B). This difference seen in T2 can be explained by the decrease in the supply of sediments in the watercourse. It happened because of the effects of the change in soil management with the adoption of conservationist practices and erosion control through the implementation of technical projects at the 196 properties that were recovered with conservationist agriculture, through the work performed (Figures 3B, 3D, 3E, 3G, 3I, 3K, 3M and 3O). A similar result was found by Souza \& Gastaldini (2014), who observed that land use significantly influenced the water quality parameters. In areas considered to have a higher percentage of agriculture and with problems related to erosion, the situation of the area before the implementation of constructions, the parameters of turbidity, suspended solids are higher. This land use, without adopting conservationist practices, can be considered as having the biggest potential for erosion.

\subsubsection{Suspended Solids}

As for suspended solids, the highest values were recorded in $\mathrm{T} 1$ treatment (Figure 3C) compared to $\mathrm{T} 2$ (Figure 3D), in February all values were bigger than $100 \mathrm{mg} \mathrm{l-1} \mathrm{(milligrams} \mathrm{per} \mathrm{litre),} \mathrm{with} \mathrm{an} \mathrm{average} \mathrm{of}$ 
$252 \mathrm{mg} \mathrm{l}-1$ for that month. The same happened with the values of October $222 \mathrm{mg} \mathrm{l}-1$ and in December with an average of $416 \mathrm{mg} \mathrm{l}-1$. In T2, the values were more uniform, with averages of 126, 163 and $107 \mathrm{mg}$ l-1, only with a peak of $696 \mathrm{mg} \mathrm{l}$-1 observed in October 2012 (Figure 3D), however, it was still below the peaks recorded in the T1 in October 2006, which was $884 \mathrm{mg} \mathrm{l}-1$ and the peak observed in December 2003 with $1850 \mathrm{mg} \mathrm{l}-1$ (Figure 3C). The results of suspended solids for the rainy season were lower than those described by Setzer (1985) who evaluated soil losses and their relation to turbidity and water parameters in several watershed in the state of Sao Paulo and inferred that the averages annual rates for suspended solids in the rivers of Sao Paulo are slightly less than $150 \mathrm{mg} \mathrm{l}-1$, rising to almost $300 \mathrm{mg}$ l-1 in the rainiest months and lowering to less than $50 \mathrm{mg} \mathrm{l}-1$ in the driest months. The results of the study show that there was a significant decrease in suspended solids after the adoption of conservationist practices and the rehabilitation of agricultural properties. Rodrigues et al. (2015) evaluated that the runoff coefficient was low in the presence of vegetation resulting in bigger infiltration and better flow regularity and that erosion and carried sediments increased on unprotected soils, changing the dynamics of water on the soil.

\subsubsection{Total Phosphorus}

The total phosphorus dissolved in water in T1 (Figure 3E), presented values higher than those recommended by CONAMA Resolution 20/86, which is $0.025 \mathrm{mg} \mathrm{l}-1$ ), compared to T2 (Figure 3F). The values of phosphorus for T2 of 0.10, 0.16 and $0.16 \mathrm{mg}$ 1-1, for February, October, and December, respectively, were below the values of $0.21,0.13$ and $0,21 \mathrm{mg} \mathrm{l}-1$, except for October, the values observed in T1 were higher than those recorded in T2, except for the peaks recorded in December 2010 and October 2009 and 2012, which reached more than $0.30 \mathrm{mg} \mathrm{l-1}$, even below the peaks that occurred in T1 in 2001, 2002, 2003 and 2005, which reached $0.50 \mathrm{mg} \mathrm{l}-1$, in December 2005 (Figure 3E). The results show lower values than the values obtained by Donadio et al. (2005) who evaluated the water quality in a Watershed in Taquaritinga, SP, whose predominant soil is the Ultisol and the average values of phosphorus in the water for the dry period of the year was $1.58 \mathrm{mg}$ l-1and for the rainy season was $4.32 \mathrm{mg} \mathrm{l}-1$. The results of phosphorus, found by Pinheiro et al. (2014), who studied the use and occupation of soil and the relation to water quality in two sub-areas of Rio Duas Mamas Watershed in Santa Catarina, were 27.3 and $41.6 \mathrm{mg} \mathrm{l}-1$ and, were higher than the results found in the present study. This was because in SW2 there were banana cultivation and cultivation areas for annual cycle crops, despite the large percentage of remaining natural forest, in both cases.

\subsubsection{Organic Carbon}

As for the organic carbon dissolved in water $(\mathrm{C})$, the data were higher in $\mathrm{T} 1$ with averages of $9.76,10.50$ and $8.55 \mathrm{mg}^{-1}$, in all months of February, October and December respectively, reaching values of $\mathrm{C}$ above $19 \mathrm{mg} 1^{-1}$ in 2000. In treatment T2, the average carbon values of $6.25,5.88$ and $4.90 \mathrm{mg}^{-1}$, for the same months, were between 4.9 and $6,2 \mathrm{mg} 1^{-1}$ while at T1, they were between 8.5 and $10.5 \mathrm{mg}^{-1}$ (Figure $3 \mathrm{G}$ ). It ensures that the amount of $\mathrm{C}$ in the water after the implementation of the project was lower than the situation before the implementation of the project, in this case, the conservationist practices implemented contributed to a smaller amount of eroded sediments, a result that corroborates with Silva et al. (2005) that in their study the organic $\mathrm{C}$ was the constituent found in bigger quantity in eroded sediments, emphasizing the need for conservationist practices that reduce the erosive action of rain, maintaining this organic fraction in the soil.

\section{CONCLUSIONS}

After 20 years of applying the conservation legislation, 772 thousand hectares have already been worked in the state of Sao Paulo, with 19,846 agricultural properties that were assessed and rehabilitated agroecologically.

The inspection of Rio do Peixe Watershed, carried out from 2007 to 2019, with inspections, diagnostics, and rehabilitation of agricultural properties, is transforming them into conservationists, preserving the soil and water, taking care of the well-being of the local society.

Implementation of the Integrated Crop-Livestock Systems, with the change in soil and pasture management, 
increased the occupation rate of areas with pastures, by $31 \%$, compared to the original situation.

The Innovated CDA Methodology presents a positive yield of $1377 \%$ in comparison to the conventional CDA Methodology, saving capital and the human resources of Agricultural Defense.

In these twelve years of study at Rio do Peixe Watershed, new technologies have been developed for the site, such as Bioengineering, No-Tillage, and Integrated Crop-Livestock, a fact that has changed the habit of how to treat natural resources of large farmers in the region.

The agri-environmental monitoring and rehabilitation methodology is feasible and can contribute to the management and monitoring of the watersheds.

The work carried out in the watershed transformed, in most cases, conventional, degrading agriculture, into conservation agriculture.

\section{ACKNOWLEDGEMENTS}

The authors thank the Agrisus for their financial support for the dissemination of CDA's Soil Conservation works at the XIX Congreso Latinoamericano de la Ciencia del Suelo, 7th World Congress on Conservation Agriculture e Global Symposium on Soil Erosion, and the Engineers Agronomists who worked on this project.

\section{REFERENCES}

Albernaz, W. M. \& Lima, J. M. (2007). Caracterizacao da cobertura vegetal de pastagens em duas subbacias hidrograficas da regiao de Lavras, MG. Ciencia e Agrotecnologia, 31, n.2, p.290-297. http://dx.doi . org/10.1590/S1413-70542007000200004

Araujo, L. E., Santos, M. J., Duarte, S. M., Oliveira, E. M. (2009). Impactos ambientais em bacias hidrograficas - caso da bacia do Rio Paraiba. TECNO-LOGICA, 13 , n.2, p.109-115.

http://dx.doi.org/10.17058/tecnolog.v13i2.855

Bezerra, M. A., Etchebehere, M. L. C., Saad, A. R., Casado, F. C. (2009). Analise geoambiental da regiao de Marilia, SP: suscetibilidade a processos erosivos frente ao historico de ocupacao da area. Geociencias, 28, n. 4, p.425-440.

http://www.ppegeo.igc.usp.br/index.php/GEOSP/article/view/7087/6532

Bezerra, J. F. R., Guerra, A. J. T., Rodrigues, S.C. (2012). Relacoes entre potencial matricial no solo e cobertura vegetal em uma estacao experimental, Uberlandia - MG. Sociedade \& Natureza, ano 24, n.1, p.103-114. http://dx.doi.org/10.1590/S1982-45132012000100009

CONAMA (1986) - Conselho Nacional de Meio Ambiente. Resolucao CONAMA 20/86 de 18 de junho de 1986, dispoe sobre a qualidade das aguas. Brasilia: publicacao no Diario Oficial da Uniao de 30/07/1986. Available: http://www.icmbio.gov.br/cepsul/images/stories/legislacao/Portaria/1986/res_ conama_20_1986_revgd_classificacaoaguas_altrd_res_conama_274_2000_revgd_357_2005.pdf

Donadio, N. M. M., Galbiatti, J. A., Paula, R. C. (2005). Qualidade da agua de nascentes com diferentes usos do solo na bacia hidrografica do Corrego Rico, Sao Paulo, Brasil. Engenharia Agricola, 25 , n.1, p.115-125.

http://dx.doi.org/10.1590/S0100-69162005000100013

FAO (2019). Food and Agriculture Organization of the United Nations. Agricultura Conservacionista, Definicao. Available: http://www.fao.org/conservation-agriculture/en/. Accessed 03/04/2019.

Lelis, T. A., Calijuri, M. L. A. (2010). Modelagem hidrossedimentologica de bacia hidrografica na regiao sudeste do Brasil, utilizando o SWAT. Ambi-Agua, 5 , n.2, p.158-174. doi: 10.4136/ambi-agua.145. 
Lepsch, I. F., Espindola, C. R., Vischi Filho, O. J., Hernani, L. C., Siqueira, D. S. (2015). Manual para levantamento utilitario e classificacao de terras no sistema de capacidade de uso. Sociedade Brasileira de Ciencia do Solo. Vicosa. 170 p.

Lima, E. A. C. F., Silva, H. R., Altimare, A. L. (2004). Uso atual da terra no municipio de Ilha Solteira, SP, Brasil: riscos ambientais associados. Holos Environment, 4 , p.81-96. doi:10.14295/holos.v4i2.353.

Minella, J. P. G., Merten, G. H.; Reichert, J. M., Santos, D. R. (2007). Identificacao e implicacoes para a conservacao do solo das fontes de sedimentos em bacias hidrograficas. Revista Brasileira de Ciencia do Solo, 31 , p.1637-1646, 2007.

http://dx.doi.org/10.1590/S0100-06832007000600039

Menezes, M. D., Curi, N., Marques, J. J., Mello, C. R., Araujo, A. R. (2009). Levantamento pedologico e sistema de informacoes geograficas na avaliacao do uso das terras em sub-bacia hidrografica de Minas Gerais. Ciencia e Agrotecnologia, 33, n.6.

http://dx.doi.org/10.1590/S1413-70542009000600013

Pruski, F. F. (2006). Conservacao de solo e agua: praticas mecanicas para o controle da erosao hidrica. Vicosa-MG: Editora UFV. 240 p.

Pinheiro, A., Schoen, C., Schultz, J., Heinz, K. G. H., Pinheiro, I. G., Deschamps, F.C. (2014). Relacao entre o uso do solo e a qualidade da agua em bacia hidrografica rural no bioma mata atlantica. Revista Brasileira de Recursos Hidricos, 19 , n.3, p. 127-139. http://dx.doi.org/10.21168/rbrh.v19n3.p127-139

Rodrigues, V. A., Sanchez-Roman, R. M., Tarjuelo, J. M., Sartori, M. M. P., Canales, A. R. (2015). Avaliacao do escoamento e interceptacao da agua das chuvas. Irriga, Ed. Esp. 20 anos Irriga +50 anos FCA, p.1-13.

https://doi.org/10.15809/irriga.2015v1n1p01

Santos, V. G., Dias, H. C. T., Silva, A. P. S., Macedo, M. N. C. (2007). Analise hidrologica e socioambiental da bacia hidrografica do corrego Romao dos Reis, Vicosa, MG. Revista Arvore, 31 , n.5, p.931-940.

http://dx.doi.org/10.1590/S0100-67622007000500017

Santos, J. B., Pezzoni Filho, J. C., Dantas, M. J. F., Zimback, C. R. L., Lessa, L. G. F. (2014). Avaliacao da adequacao da ocupacao do solo em areas de Preservacao permanente (APPs). Irriga, 19 , n.2, p.333-344.

https://doi.org/10.15809/irriga.2014v19n2p333

Santos, H. G., Jacomine, P. K. T., Anjos, L. H. C., Oliveira, V. A., Lumbreras, J. F., Coelho, M. R., Almeida, J. A., Araujo Filho, J. C., Oliveira, J. B., Cunha, T. J. F. (2018). Sistema Brasileiro de Classificacao de Solos. 5a Ed. Revista e Ampliada, Brasilia, Embrapa. 353 p.

Sao Paulo, Estado (1988). Diario Oficial do Estado de Sao Paulo,98 , n.123, 05/07/88. Lei ndeg 6.171, de 04 de julho de 1988. Dispoe Sobre o Uso, Conservacao e Preservacao do Solo Agricola. Sao Paulo.

Setzer, J. (1985). Transporte solido por suspensao em rios paulistas. CTH/DAEE/EPUSP. Sao Paulo. 106p. Available: https://pt.scribd.com/document/103336296/TRANSPORTE-SOLIDO-POR-SUSPENSAO-EMRIOS-PAULISTAS-Livro\#download

Silva, A. M., Silva, M. L. N., Curi, N., Lima, J. M., Avanzi, J. C., Ferreira, M. M. (2005). Perda de solo, agua, nutrientes e carbono organico em cambissolo e latossolo sob chuva natural. Pesquisa Agropecuaria Brasileira, 40, p.1223-1230, 2005. http://dx.doi.org/10.1590/S0100-204X2005001200010

Silva, A. M., Silva, M. L. N., Curi, N., Avanzi, J. C., Ferreira, M. M. (2009). Erosividade da chuva e erodibilidade de Cambissolo e Latossolo na regiao de Lavras, Sul de Minas Gerais. Revista Brasileira de Ciencia do Solo, 33, p.1811-1820. http://dx.doi.org/10.1590 /S0100 -06832009000600029 
Vischi Filho, O. J., Corsato, L. G., Quiessi, J. A., Kanno, O. Y., Penteado, R. B., Arabori, R. M., Belorte, L. C. C., Lima, M. E., (2016). Diagnostico e reabilitacao agroambiental de trecho de bacia hidrografica por sensoriamento remoto e turbidez da agua. Pesquisa Agropecuaria Brasileira, 51 (9), 1099-1109.

http://dx.doi.org/10.1590/s0100-204x2016000900009

Vischi Filho, O. J., Kanno, O. Y., Penteado, R. B., Arabori, R. M., Caldas, J. F. B., Mota, M. R., ... Abreu, F. C. (2017). Methodology for diagnosis of degraded areas using aerial images and validation using photos obtained with drone. In: Anais of 7th Word Congress on Conservation Agriculture. Rosario, AR.

Vischi Filho, O. J., Kanno, O. Y., Penteado, R. B., Arabori, R. M., Caldas, J. F. B., Tristao, F. S. M., ... Scachetti, E. A. M. (2018). Comparation between Diagnostic Metodology CDA versus Methodology CDA Innovated aiming to transform degraded areas into conservation agriculture areas. In: Anais $21^{\text {st }}$ World Congress of Soil Science. Rio de Janeiro. Brazil. Available: https://www.21wcss.org/docs/21wcss_programacao_final.pdf. p.130.

Vischi Filho, O. J., Kanno, O. Y., Penteado, R. B., Arabori, R. M., Caldas, J. F. B., Quiessi, J. A., Scachetti, E. A. M., Camargo, M. B. (2019). Agricultural Defense of Sao Paulo: Twelve years of soil preservation and rehabilitation at the Rio do Peixe watershed, promoting conservation agriculture. In book: Proceedings of the Global Symposium on Soil Erosion 2019. Publisher: FAO. Rome, IT.

Zalidis, G., Stamatiadis, S., Takavakoglou, V., Eskridge, K., Misopolinos, N. (2002). Impacts of agricultural practices on soil and water quality in the Mediterranean region and proposed assessment methodology. Agriculture, Ecosystems and Environment, 88 , p.137-146.

https://doi.org/10.1016/S0167-8809(01)00249-3

Zolin, C. A., Folegatti, M. V., Mingoti, R., Sanchez-Roman, R. M., Paulino, J., Gonzales, A. M. G. O. (2011). Minimizacao da erosao em funcao do tamanho e localizacao das areas de floresta no contexto do programa "conservador das aguas". Revista Brasileira de Ciencia do Solo, 35 , p.2157-2166.

http://dx.doi.org/10.1590/S0100-06832011000600030

Table 1. Erosions and other soil degradation found at Rio do Peixe watershed during diagnosis

\begin{tabular}{llll}
\hline Municipality & Vera Cruz & Ocauçu & Marília \\
\hline Crops Grown & Area (ha) & Area (ha) & Area (ha) \\
Coffee & 2232 & 521 & 45 \\
Pasture & 9799 & 5726 & 14947 \\
Vegetables + & 14 & 36 & 10 \\
Annual crops ++ & 12 & 69 & 100 \\
Passion fruit & 13 & 11 & 1 \\
Eucalyptus & 41 & 33 & 21 \\
Sugar cane & 8 & 26 & 3 \\
Fruit trees & 106 & 25 & 5 \\
Manioc & 20 & 312 & 939 \\
Natural Forest & 1214 & 1745 & 7647 \\
APP $\S$ & 449 & 408 & 3836 \\
Others $\mathbf{~}$ & 168 & 115 & 221 \\
Watershed Area & $\mathbf{1 4 0 7 6}$ & $\mathbf{9 0 2 7}$ & $\mathbf{2 7 7 7 5}$ \\
\hline
\end{tabular}

Table 2. Land Use and Occupation in Rio do Peixe watershed

+ Vegetables: pumpkin, lettuce, cabbage, parsley, chive. ++ Annual crops: corn, soybean, wheat. § Permanent Preservation Area. I Others: roads, rivers, farms improvements, warehouse. 
Table 3. Cattle herd evolution in Rio do Peixe Watershed. 2009/2010 prior to the work completion. 2016/2017 after pastures recovery

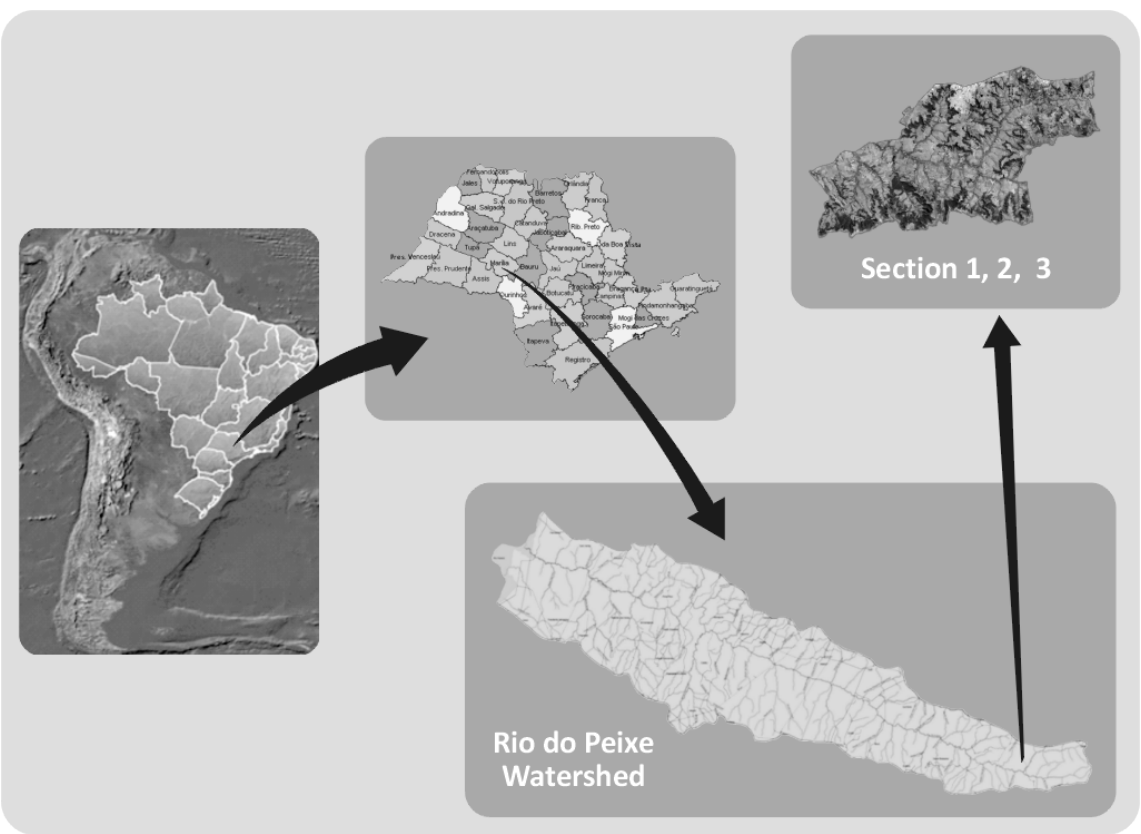



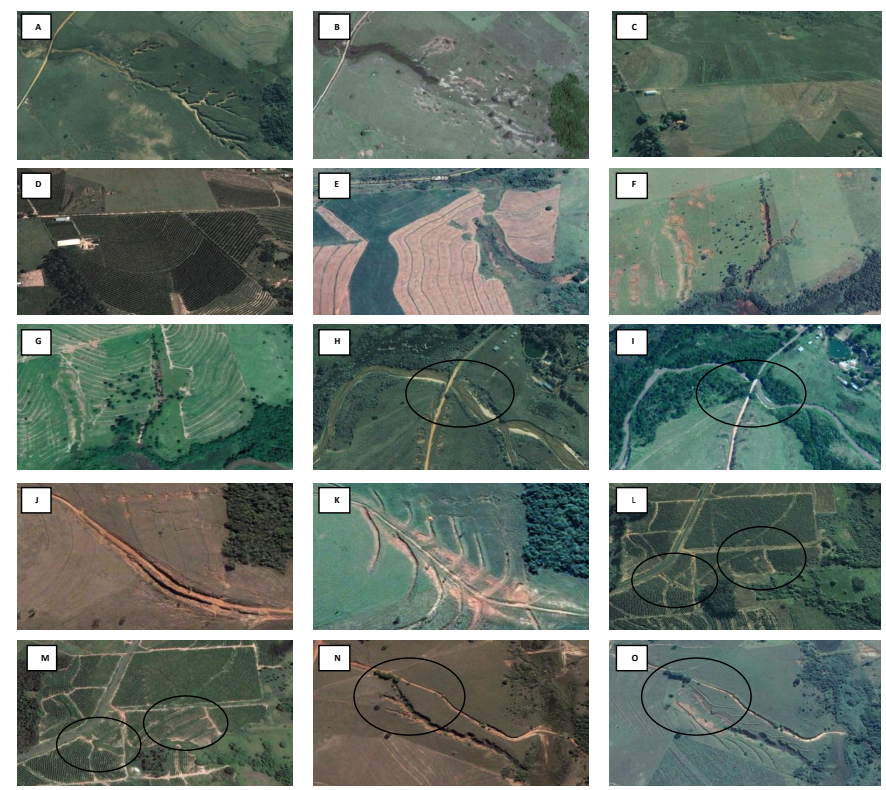


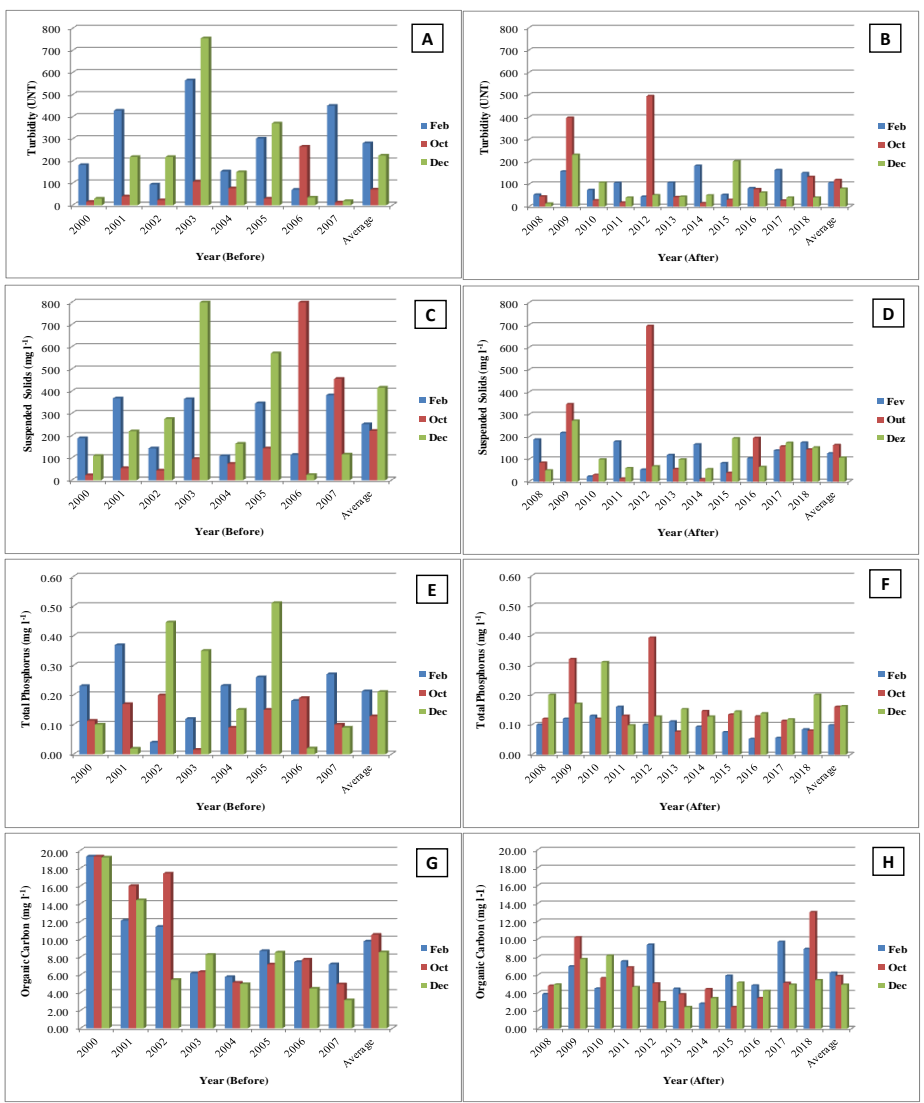

